\title{
Infection of Blueberry Cultivar 'Emerald' with a California Pierce's Disease Strain of Xylella fastidiosa and Acquisition by Glassy-Winged Sharpshooter
}

\author{
Lindsey P. Burbank ${ }^{\dagger}$, Mark S. Sisterson, and Michael L. O'Leary \\ United States Department of Agriculture, Agricultural Research Service, San Joaquin Valley Agricultural Sciences Center, \\ Parlier, CA 93648
}

Abstract

\begin{abstract}
Bacterial leaf scorch disease caused by Xylella fastidiosa occurs in southern highbush blueberry varieties in the southeastern United States. Susceptibility to $X$. fastidiosa varies by blueberry cultivar, and these interactions are often strain-specific. Xylella fastidiosa subsp. fastidiosa is the causal agent of Pierce's disease in grapevines, and it has been problematic in the San Joaquin Valley of California since the introduction of the glassywinged sharpshooter (Homalodisca vitripennis). The glassy-winged sharpshooter is known to feed on blueberry, a crop that is expanding in the San Joaquin Valley. Currently, little is known about the potential for the spread of $X$. fastidiosa between grape and blueberry in this region. The ability of a Pierce's disease strain of $X$. fastidios $a$ from the San Joaquin Valley to cause
\end{abstract}

disease in southern highbush blueberry and the potential for the glassywinged sharpshooter to transmit $X$. fastidiosa between blueberry and grapevine were investigated. Experimental inoculations showed that the $X$. fastidiosa subsp. fastidiosa strain Bakersfield-1 can cause disease in blueberry cv. Emerald, and that the glassy-winged sharpshooter can acquire $X$. fastidiosa from artificially inoculated blueberry plants under laboratory conditions. Understanding the possibility for $X$. fastidiosa strains from the San Joaquin Valley to infect multiple crops grown in proximity is important for area-wide pest and disease management.

Keywords: fruit, prokaryotes, small fruits
Bacterial leaf scorch disease caused by Xylella fastidiosa commonly occurs in southern highbush and rabbit eye blueberry varieties in the southeastern United States (Chang et al. 2009). This disease is characterized by marginal leaf scorch symptoms that progress to leaf necrosis, defoliation, loss of fruit yield, and death of the plants (Chang et al. 2009). The first strains of $X$. fastidiosa isolated from blueberry in this region were classified as $X$. fastidiosa subsp. multiplex, the genetic group of Xylella strains known to cause disease in almond, peach, oak, and sycamore (Hopkins and Purcell 2002). Further genetic characterization of blueberry-infecting strains revealed genetic differences from previously described $X$. fastidiosa subsp. multiplex strains (Nunney et al. 2014; Van Horn et al. 2017), which were potentially the result of horizontal gene transfer and recombination between $X$. fastidiosa subsp. fastidiosa and subsp. multiplex (Nunney et al. 2014). Additionally, some strains of $X$. fastidiosa subsp. fastidiosa, the causal agent of Pierce's disease of grapevine, have been reported to cause disease of blueberry under greenhouse conditions (Oliver et al. 2015). Susceptibility to bacterial leaf scorch varies by blueberry cultivar, and these interactions can be strain-specific (Holland et al. 2014; Oliver et al. 2015). Since the first report in Georgia, bacterial leaf scorch of blueberry has been identified in Florida, Kentucky, and Louisiana (Chang et al. 2009; Ferguson and Clark 2017; Harmon and Hopkins 2009; Leonberger and Gauthier 2015).

${ }^{\dagger}$ Corresponding author: L. Burbank; lindsey.burbank@ars.usda.gov

Funding: Funding for this project was provided by United States Department of Agriculture-Agriculture Research Service appropriated project no. 203422000-012-00D. Mention of trade names or commercial products in this publication is solely for the purpose of providing specific information and does not imply recommendation or endorsement by the United States Department of Agriculture. The USDA is an equal opportunity provider and employer.

*The $\boldsymbol{e}$-Xtra logo stands for "electronic extra" and indicates that three supplementary figures are published online.

The author(s) declare no conflict of interest.

Accepted for publication 26 July 2019.

This article is in the public domain and not copyrightable. It may be freely reprinted with customary crediting of the source. The American Phytopathological Society, 2020.
Spread of $X$. fastidiosa is reliant on transmission by xylem-feeding insect vectors (Krugner et al. 2019), and the glassy-winged sharpshooter (Homalodiscus vitripennis) has been implicated in outbreaks of bacterial leaf scorch in blueberry in the southern United States (Chang et al. 2009; Harmon and Hopkins 2009; Tertuliano et al. 2012). In the San Joaquin Valley of California, Pierce's disease caused by $X$. fastidiosa subsp. fastidiosa has been problematic over the past 20 years since the introduction of the glassy-winged sharpshooter to southern California. Additionally, in the San Joaquin Valley, it is common to find multiple crops grown in close proximity that are confirmed or potential hosts for $X$. fastidios $a$ and glassywinged sharpshooter, thus complicating disease management. Area-wide pest control programs have been in place since 2001 to manage glassy-winged sharpshooter populations, particularly in vineyards (Pierce's disease) and citrus orchards (overwintering host for glassy-winged sharpshooter) (Haviland and Stone-Smith 2016; Perring et al. 2001). During the early 2000s, vector populations in Kern County, California, were successfully controlled by area-wide insecticide treatments; however, resurgent glassywinged sharpshooter populations in 2012 to 2015 led to increased Pierce's disease incidence and greater potential for the spread of $X$. fastidiosa in the area (Haviland and Stone-Smith 2016). The blueberry cultivars typically planted in the San Joaquin Valley are southern highbush varieties, and many of these are known to be susceptible to $X$. fastidiosa (Holland et al. 2014; Tertuliano et al. 2012), thereby highlighting the need for more information regarding the potential risk of bacterial leaf scorch disease in California.

The goals of this study were to evaluate a Pierce's disease-causing $X$. fastidiosa strain for the ability to induce bacterial leaf scorch symptoms in blueberry and the potential of the glassy-winged sharpshooter to act as a vector for bacterial leaf scorch-associated strains of $X$. fastidiosa in the San Joaquin Valley of California. Understanding the likelihood of $X$. fastidiosa transmission from blueberry to grape, and vice versa, is important for evaluating risks associated with expanding blueberry acreage into areas where Pierce's disease strains of $X$. fastidiosa are prevalent.

\section{Materials and Methods}

Plant material and experimental inoculations. Five southern highbush blueberry cultivars (Vaccinium sp. Hybrids 'Emerald', 
'Star', 'Jewel', 'Misty', and 'O'Neal') were screened for susceptibility to a $X$. fastidiosa strain (Bakersfield-1) isolated from grapevines (Burbank and Ortega 2018) exhibiting Pierce's disease symptoms in Kern County, CA. Two-year-old blueberry plants in 3.8-liter pots were obtained from a commercial nursery and grown in a greenhouse

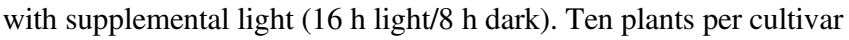
were artificially inoculated by needle prick on three separate stems with a total of $60 \mu$ l of cell suspension $\left(\approx 10^{8} \mathrm{CFU} / \mathrm{ml}\right.$ in $1 \times$ phosphate-buffered saline [PBS]), and five additional plants per cultivar were inoculated with buffer alone to serve as negative controls. Plants were evaluated for symptom development over the course of 4 months. At the end of the evaluation period, stem and leaf samples were collected for bacterial isolation and testing by quantitative PCR (qPCR). Cultivars that had detectable levels (PCR and culture positive) of $X$. fastidiosa colonization ('Emerald' and 'O'Neal') were included in a second round of inoculations with 15 plants per cultivar inoculated in the same manner.

Evaluation of infection status. During the 4-month evaluation period after inoculation, symptom severity was evaluated using the 0 to 7 rating scale developed by Oliver et al. (2015): $0=$ asymptomatic and $7=$ severe disease (defoliation). The $5-\mathrm{cm}$ stem sections were collected for bacterial isolation from a different branch than the one inoculated. Stem sections were surface-sterilized by successive washes in $70 \%$ ethanol and $10 \%$ sodium hypoclorite (Fisher Scientific, Waltham, MA), followed by two washes with sterile $\mathrm{dH}_{2} \mathrm{O}$. Then, stems were crushed in $2 \mathrm{ml} 1 \times$ PBS, serially diluted, plated on PD3 medium, and incubated at $28^{\circ} \mathrm{C}$. After 10 days of incubation, colonies were confirmed as $X$. fastidiosa by PCR using speciesspecific primers (Hernandez-Martinez et al. 2006).

Plants were also independently sampled and tested for the presence and quantity of $X$. fastidiosa via qPCR. Leaf midribs and petioles from five leaves from each plant were excised and combined. Samples were lyophilized and ground mechanically for DNA extraction. Each sample was mixed with $1 \mathrm{ml}$ of lysis buffer consisting of $50 \mathrm{mM}$ EDTA, $100 \mathrm{mM}$ Tris- $\mathrm{HCl}$ (pH 8), $0.25 \mathrm{mg} / \mathrm{ml}$ proteinase $\mathrm{K}$, $3.5 \% \mathrm{SDS}, 10 \mathrm{mg} / \mathrm{ml}$ sodium bisulfite, and $2.5 \%$ polyvinylpyrridone. After 15 min of incubation at $65^{\circ} \mathrm{C}$, samples were centrifuged at $14,000 \mathrm{rpm}$ for $5 \mathrm{~min}$; the upper phase was removed and mixed with $200 \mu \mathrm{l}$ of $7.5 \mathrm{M}$ ammonium acetate. Samples were incubated on ice for $15 \mathrm{~min}$ and centrifuged at 14,000 rpm for $3 \mathrm{~min}$; the supernatant was removed and placed in a new tube. Nucleic acid was then precipitated with an equal volume of isopropanol and washed twice with $70 \%$ ethanol. The DNA pellet was resuspended in $50 \mu \mathrm{l}$ TE buffer for storage and diluted $1: 10$ in sterile $\mathrm{dH}_{2} \mathrm{O}$ for qPCR analysis. Then, $5 \mu \mathrm{l}$ of total DNA was used as the qPCR template. A qPCR was performed using Applied Biosystems Fast SYBR Green Master Mix (Fisher Scientific) and X. fastidiosa-specific primers targeting the 16S rRNA sequence (Burbank and Stenger 2016). Quantification was based on a standard curve consisting of DNA extracted from known cell concentrations of $X$. fastidiosa $\left(10^{2}\right.$ to $\left.10^{7} \mathrm{CFU} / \mathrm{ml}\right)$ combined with DNA extracted from uninoculated blueberry plants (1:2 ratio of bacterial:plant DNA). A $C_{t}$ value of $\leq 30$ cycles was considered PCR-positive. The quantity of $X$. fastidiosa (CFU) was normalized to the total DNA concentration.

Insect transmission experiments. Glassy-winged sharpshooter eggs were collected from Photinia sp. in Kern County, CA, in Apr. 2018. Nymphs were reared in a containment laboratory on a mixture of cowpea, sunflower, and sorghum. On each of two test dates, a subset of insects was taken directly from the colony and screened with qPCR to ensure that reared insects did not carry X. fastidiosa (10 on the first test date; 9 on the second test date). Subsequently, adult glassy-winged sharpshooters were caged on three X. fastidiosapositive (confirmed by qPCR and culturing) blueberry plants (cv. Emerald) for a 7-day acquisition access period (AAP; 50 on the first test date; 36 on the second test date). A subset of insects (10 on the first test date; 9 on the second test date) was taken directly from blueberry after the AAP and evaluated with qPCR to confirm acquisition. The remaining insects were transferred to 2-year-old potted grapevines (cv. Chardonnay) pruned to a single cane for a 4-day inoculation access period (IAP). To confirm that the insects fed on grapevine, they were held in individual feeding sachets attached to grapevine stems that allowed for the collection of excreta (Sisterson 2014), with each grapevine receiving three insects. At the end of the experiment, all glassy-winged sharpshooters were tested individually by qPCR for the presence of $X$. fastidiosa. All transmission experiments were conducted in a growth chamber at $27^{\circ} \mathrm{C}$ and $14 \mathrm{~h}$ light/10 h dark. For qPCR detection of $X$. fastidiosa in insects, DNA was extracted using a DNeasy Blood and Tissue kit (Qiagen, Redwood City, CA), and qPCR was performed following the protocol of Rapicavoli et al. (2015). After insects were removed, grapevines were treated with systemic insecticide and moved to a greenhouse for disease development observations. Acquisition and transmission experiments were repeated independently. The first test date used 36 insects caged on 12 grapevines, and the second test date used 24 insects caged on eight grapevines, for a total of 60 insects and 20 grapevines (three insects on each plant). Grapevines were held for 6 months and tested with qPCR as described at 12,16, 20, and 24 weeks after inoculation.

Monte Carlo simulations of transmission experiments. To complete Monte Carlo simulations, a program was written in $\mathrm{C}++$ (Visual C++; Microsoft, Redmond, WA) that simulated the transmission experiment. Each run of the program created 20 plants, with each plant receiving three insects for a total of 60 insects. As each insect was assigned to a plant, a random number between 0 and 1 was drawn; if the random number was less than the observed probability of acquisition (0.38), then the insect was assumed to have acquired $X$. fastidiosa. Subsequently, each insect that acquired $X$. fastidios $a$ was provided an opportunity to inoculate the plant it was placed on by drawing a second random number between 0 and 1 . If the random draw was less than a specified inoculation probability, then the plant became infected. For simulations, the probability of inoculation varied between 0 and 0.20 in increments of 0.0005 . For each specified inoculation probability, 1000 simulations were completed and the percentage of simulations that resulted in not observing transmission was recorded.

Isolation and characterization of Xylella fastidiosa Bakersfield1. Strain Bakersfield-1 isolated from grapevine (cv. Flame Seedless) in Kern County, CA, showed symptoms of Pierce's disease. This strain was previously identified as belonging to subspecies fastidiosa based on PCR and multi-locus sequence analysis, but genetic identity was not resolved beyond the subspecies level (Burbank and Ortega 2018). For genomic DNA extraction, $X$. fastidiosa Bakersfield-1 was grown for 5 days on PD3 agar plates at $28^{\circ} \mathrm{C}$. Cells were harvested in $1 \times$ PBS, and $1 \mathrm{ml}$ of cell suspension adjusted to approximately $\mathrm{OD}_{600}=0.5$ was used for DNA extraction with a DNeasy Blood \& Tissue kit (Qiagen) following the manufacturer's protocol for Gram-negative bacteria. After cell lysis and prior to column purification, DNA samples were treated with $20 \mu \mathrm{l}$ of RNase A $(20 \mathrm{mg} / \mathrm{ml})$ for $10 \mathrm{~min}$ at room temperature. DNA samples were eluted in $100 \mu$ of sterile $\mathrm{dH}_{2} \mathrm{O}$ and concentrated to $30 \mu \mathrm{l}$ in a Speedvac concentrator (Eppendorf, Hauppauge, NY). The DNA quantity was evaluated using a Quant-IT dsDNA fluorescent quantification kit (Life Technologies, Carlsbad, CA), with fluorescence measurements performed on an Infinite M100 Pro plate reader (Tecan, San Jose, CA). The DNA quality was evaluated by $1 \%$ agarose gel electrophoresis and stained with ethidium bromide. Samples were stored at $-20^{\circ} \mathrm{C}$.

Bakersfield-1 genome sequence and bioinformatic analysis. A Bakersfield-1 sequencing library was prepared using the 1D Native barcoding genomic DNA kit from Oxford Nanopore Technologies (Oxford, UK) and $1 \mu \mathrm{g}$ of input DNA. The library was sequenced with a MinION device (Oxford Nanopore Technologies) and base-calling was performed using Guppy software v3.0.3 (Oxford Nanopore Technologies). The complete genome of Bakersfield-1 was assembled using Canu v1.8 (Koren et al. 2017), polished via Nanopolish v0.11.0 (Loman et al. 2015), and annotated with RASTtk (Brettin et al. 2015) (NCBI Bioproject \#PRJNA545724). The fulllength nucleotide sequences for leuA, petC, malF, cysG, holC, nuoL, and $g l t T$ were extracted from genome sequences of Bakersfield- 1 and 32 additional Xylella fastidiosia strains. Sequences were aligned with PRANK (Löytynoja and Goldman 2010) and concatenated with 
FASconCAT-G (Kück and Longo 2014), and a maximum-likelihood phylogeny was generated using Mega X (Kumar et al. 2018). The sequence type was determined using the Xylella fastidiosa MLST website (https://pubmlst.org/xfastidiosa/) at the University of Oxford (Jolley et al. 2004; Scally et al. 2005). Genome and plasmid alignments were generated by Nucmer v4.0.0 (Kurtz et al. 2004), and synteny plots were visualized with a custom $\mathrm{R}$ script (Supplemental Fig. S1).

Insecticide application records and glassy-winged sharpshooter trap counts. To document glassy-winged sharpshooter activity near blueberry fields in California, trapping data from the California Department of Food and Agriculture (CDFA) were requested for the period from 2014 to 2018. Specifically, the CDFA maintains a series of sticky traps throughout California to monitor glassy-winged sharpshooter populations. Trapping data were requested from two blueberry fields located in an area with a history of increased glassy-winged sharpshooter populations and a history of Pierce's disease (Haviland and Stone-Smith 2016). Blueberry site A was 9 ha with two sticky traps maintained on the perimeter, whereas blueberry site B was 64 ha with six sticky traps maintained on the perimeter. Traps were replaced approximately every 2 weeks year-round.

To assess the risk of glassy-winged sharpshooters establishing in blueberry fields, publicly available pesticide use reports for all commercial blueberry acreage in Kern County, CA, were obtained from the Kern County Agriculture and Measurement Standards department (http://www.kernag.com/ep/permit-use/permit-use.asp) for the years 2014 to 2018 . The frequency of applications of insecticide classes documented to kill glassy-winged sharpshooters (carbamates, neonicotinoids, organophosphates, pyrethroids) (Grafton-Cardwell et al. 2003; Prabhaker et al. 2006) as well as insecticide classes that are likely to kill glassy-winged sharpshooters based on the mode of action (butenolides and ryanoids) were quantified. Insecticides with limited activity against glassy-winged sharpshooters and short residual periods such as pyrethrins (Hix 2002) were excluded. Each insecticide record was associated with a unique site identification number that reports the area treated and total area planted. The insecticide records were used to estimate the percentage of blueberry hectares that received at least one application of a compound known to kill glassywinged sharpshooters.

\section{Results}

Xylella fastidiosa Bakersfield-1 infects blueberry cv. Emerald. Of the five blueberry cultivars tested, only 'Emerald' developed significant levels of infection with $X$. fastidiosa, as indicated by symptom development, detection of $X$. fastidiosa by qPCR, and recovery of live $X$. fastidiosa from 'Emerald' stem tissue (Table 1). All other cultivars tested had only one or two plants that tested positive for $X$. fastidiosa by qPCR; no bacteria were isolated from the point of inoculation, and scorching symptoms were absent. During the second round of inoculations, 'Emerald' plants again developed moderate leaf scorch symptoms (Figs. 1 and 2) with systemic $X$. fastidiosa colonization (Fig. 3). Cultivar 'O'Neal' was included in second-round inoculations as a less susceptible control. Seven 'O'Neal' plants (out of 15) showed minor leaf scorch symptoms (Figs. 1 and 2), and low levels of $X$. fastidiosa colonization (Fig. 3).

Table 1. First-year cultivar screen of blueberry plants 20 weeks after inoculation with $X$. fastidiosa Bakersfield-1

\begin{tabular}{lcc}
\hline $\begin{array}{l}\text { Blueberry cultivar } \\
\text { (Vaccinium } \text { sp.) }\end{array}$ & $\begin{array}{c}\text { qPCR-positive plants } \\
\text { after 20 } \mathbf{w k}^{\mathbf{a}}\end{array}$ & $\begin{array}{c}\text { Culture-positive } \\
\text { plants }\end{array}$ \\
\hline Star & $2 / 10$ & $0 / 10$ \\
Emerald & $5 / 10$ & $5 / 10$ \\
Jewel & $2 / 10$ & $0 / 10$ \\
Misty & $1 / 10$ & $0 / 10$ \\
O'Neal & $2 / 10$ & $1 / 10$ \\
\hline
\end{tabular}

a Plant samples with a $\mathrm{C}_{\mathrm{t}}$ value $<30$ cycles were considered positive for $X$. fastidiosa. Negative control plants (mock inoculated) were included in qPCR testing and did not show any amplification.
Glassy-winged sharpshooters can acquire $X$. fastidiosa from blueberry. Testing of a subset of insects immediately after the 7-day AAP on blueberry indicated that $58 \%$ (11 out of 19 over two test dates) tested positive for $X$. fastidiosa (Fig. 4A). All insects (19 over two test dates) tested directly from the source colony were negative for $X$. fastidiosa (Fig. 4A). After the AAP on blueberry, a total of 60 insects were confined on grapevines ( 3 insects per vine) for a 4-day IAP in individual feeding sachets that allowed for measurement of excreta production. Of the 60 insects moved to grapevine, $92 \%$ survived to the end of the 4-day IAP. Feeding on grapevine was confirmed, with insects producing an average $( \pm \mathrm{SE})$

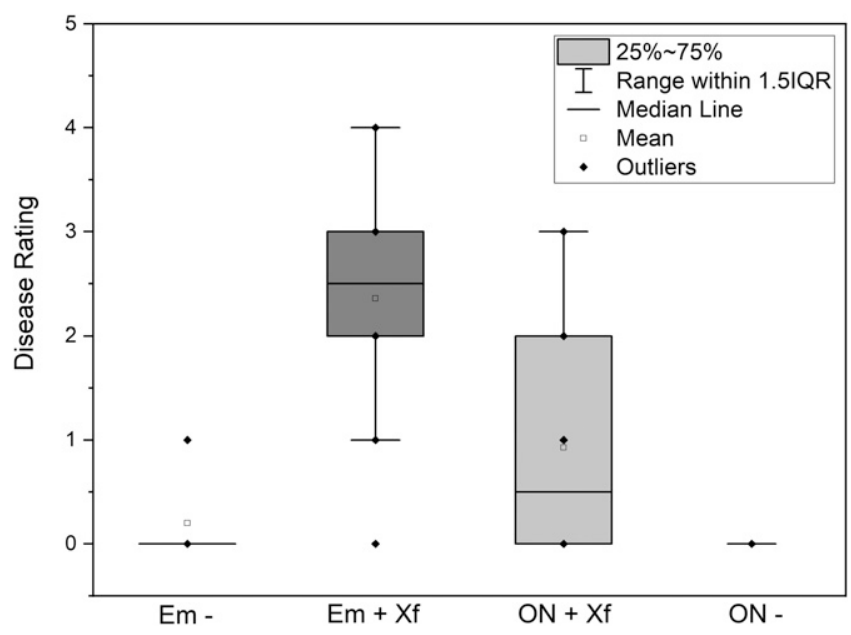

Fig. 1. Disease rating of blueberry cultivars 'Emerald' and 'O'Neal' at 4 months after inoculation with Xylella fastidiosa strain Bakersfield-1. Leaf scorch symptoms of blueberry cultivars 'Emerald' (Em) and 'O'Neal' (ON) were evaluated at 4 months after inoculation with $X$. fastidiosa strain Bakersfield-1. Disease ratings were assigned using the 0 to 7 rating scale developed by Oliver et al. (2015), where $0=$ asymptomatic and $7=$ severe disease (i.e., defoliation). Fifteen plants of each cultivar were needle-inoculated with $X$. fastidiosa strain Bakersfield-1. Cultivar 'Emerald' plants inoculated with $X$. fastidiosa strain Bakersfield-1 showed significant disease development (Tukey means comparison test, $P<0.001$ ), whereas the mean disease rating of cultivar 'O'Neal' plants inoculated with strain Bakersfield-1 was not significantly different from that of mock-inoculated control plants, despite showing mild scorch symptoms.

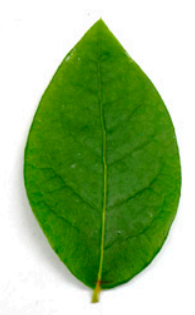

Em -
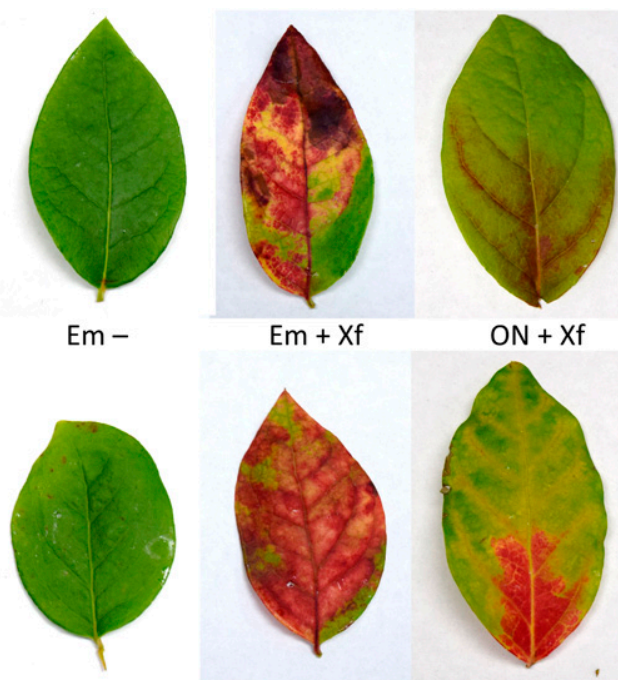

$\mathrm{ON}+\mathrm{Xf}$

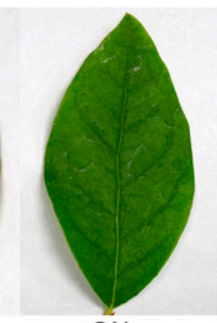

ON -

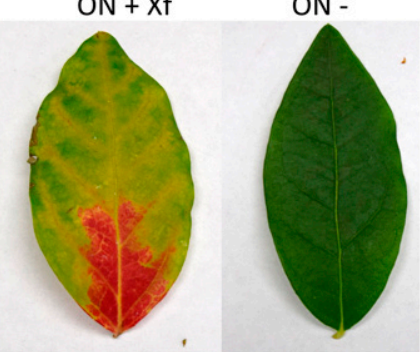

Fig. 2. Leaf scorch symptoms of blueberry inoculated with Xylella fastidiosa strain Bakersfield-1. Representative leaf scorch symptoms of blueberry cultivars 'Emerald' $(E m)$ and 'O'Neal' (ON) inoculated with $X$. fastidiosa strain Bakersfield-1 (Xf) compared with mock-inoculated (-) control plants. Photos were taken at 4 months after inoculation. Top and bottom panels show leaves from different plants. 
of $5.3 \pm 0.6 \mathrm{ml}$ of excreta over the 4-day IAP. At the end of the transmission experiments, $38 \%$ ( 21 out of 55 over both test dates and excluding insects that died during the IAP) of insects tested positive for $X$. fastidios $a$ by qPCR. However, after being held in the greenhouse for 6 months, none of the 20 grapevines tested positive for $X$. fastidiosa, and no visible Pierce's disease symptoms were observed.

Because transmission of $X$. fastidiosa by the glassy-winged sharpshooter is considered inefficient compared with other vector species (Almeida and Purcell 2003), it is possible that transmission would not be observed if probabilities of acquisition and/or inoculation are low. Based on qPCR data, we concluded that $38 \%$ of insects provided with an IAP had acquired $X$. fastidiosa. To estimate a range for the probability of inoculation over the 4-day IAP without observing transmission, a Monte Carlo simulation method was used (Manly 2001).

Based on the simulations, for an experiment using 20 plants and a 0.38 chance of acquiring $X$. fastidiosa during the AAP, the probability of not observing transmission decreased as the probability of inoculation over the 4-day IAP increased (Fig. 4B). With an inoculation probability of 0.13 during the IAP, there was a $5 \%$ chance of not observing transmission. Therefore, it is reasonable to estimate that the probability of inoculation resulting in infection over a 4-day IAP is within the range of 0 and 0.13 .

Genetic characterization of $X$. fastidiosa subsp. fastidiosa strain Bakersfield-1. The genome sequence was assembled into a single $\approx 2.5-\mathrm{Mb}$ circular chromosome and one $\approx 38$-kb circular plasmid, with $\approx 133$-times average coverage. A multi-locus sequence typing analysis using the scheme described previously by Scally et al. (2005) classified Bakersfield-1 as ST1, and a maximum-likelihood phylogeny generated from concatenated full-length housekeeping genes grouped strain Bakersfield-1 with typical X. fastidiosa subsp. fastidiosa strains originating from California (e.g., M23 and Temecula-1) (Supplemental Fig. S2). The Bakersfield-1 chromosome was colinear with that of $X$. fastidiosa subsp. fastidiosa strains M23 (Fig. 5A) and Temecula-1 (Supplemental Fig. S3). The 38-kb plasmid had high nucleotide sequence identity (99.99\%) to and was colinear with pXFAS01 from M23 (Fig. 5B); this plasmid is absent from Temecula-1.

Glassy-winged sharpshooters are infrequently found in blueberries planted near vineyards. Trap catches of glassy-winged sharpshooters on the perimeter of blueberry fields were low in 2014, peaked in 2015, and declined to low levels in 2016 (Fig. 6A). In 2017 and 2018, only a single glassy-winged sharpshooter was caught.

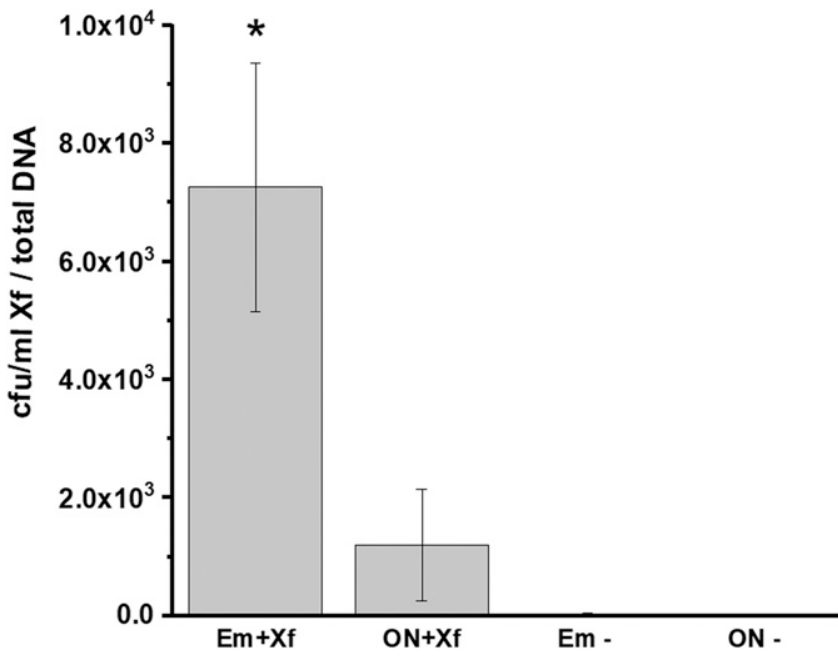

Fig. 3. Quantification of Xylella fastidiosa populations in infected blueberry plants by quantitative PCR (q-PCR). Leaf midribs and petioles from five leaves on each plant were excised and combined for DNA extraction. Quantification of bacterial CFU is based on a standard curve consisting of DNA extracted from known cell concentrations of $X$. fastidiosa $\left(10^{2}\right.$ to $\left.10^{7} \mathrm{CFU} / \mathrm{ml}\right)$ combined with DNA extracted from uninoculated blueberry plants (1:2 ratio of bacterial:plant DNA). Ct values of $\leq 30$ cycles that had a single melt curve peak were included in quantification. *Significant differences based on an analysis of variance (ANOVA) followed by a Tukey means comparison test $(P<0.001)$.
Blueberry site A was managed as three blocks. Two of the three management blocks at blueberry site A were not treated with a compound in an insecticide class known to affect glassy-winged sharpshooters between 2014 and 2018. However, one block at blueberry site A was treated with applications of a neonicotinoid, a pyrethroid, and an organophosphate in 2016. No insecticide treatments affecting glassy-winged sharpshooters were reported at blueberry site B between 2014 and 2018. Across Kern County, blueberry fields were treated with insecticides from several classes likely to affect glassy-winged sharpshooters, including butenolides, carbamates, neonicotinoids, organophosphates, pyrethroids, and ryanoids. Across years, the percentage of blueberry production in Kern County reporting at least one treatment affecting glassy-winged sharpshooters ranged between 32 and 66\%, with higher insecticide use in 2014 through 2016 than in 2017 and 2018 (Fig. 6B). Therefore, many blueberry fields in Kern County did not receive treatments that limited glassy-winged sharpshooter establishment during years of high local abundance.

\section{Discussion}

Blueberry acreage in California has more than doubled in the past 10 years, producing more than $\$ 34$ million of fresh market
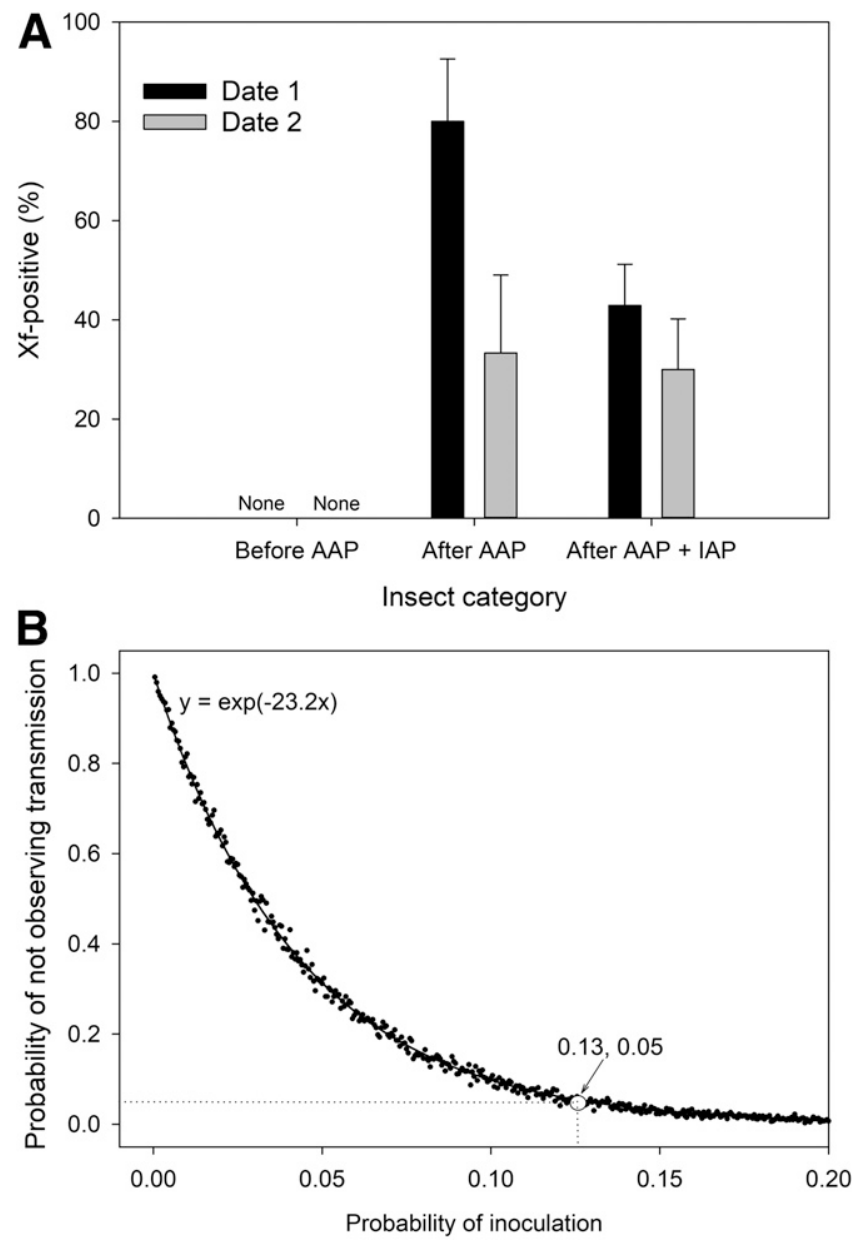

Fig. 4. Glassy-winged sharpshooter acquisition of Xylella fastidiosa from blueberry. A, Percentage $( \pm \mathrm{SE})$ of glassy-winged sharpshooters testing positive for $X$. fastidiosa prior to the acquisition access period (AAP) on blueberry, directly after the AAP on blueberry, and after the inoculation access period (IAP) on grapevine. Date 1 included 10 insects tested before the AAP, 10 insects tested after the AAP, and 35 insects tested after the IAP (insects that died during the IAP were excluded). Date 2 included 9 insects tested before the AAP, 9 insects tested after the AAP, and 20 tested after the IAP (insects that died during the IAP were excluded). B, Results of Monte Carlo simulations used to estimate the probability of not observing transmission assuming a probability of acquisition during the AAP of 0.38 . Each point represents the proportion of 1000 simulations in which transmission was not observed. The dashed line indicates the $5 \%$ value for not observing transmission during an experiment that used 20 plants, with each plant receiving 3 insects. 
blueberries in 2017 (NASS 2019). Although bacterial leaf scorch disease caused by $X$. fastidiosa has not been reported in blueberries in California to date, this pathogen and its insect vectors are present in some areas where blueberries are grown (Haviland and StoneSmith 2016), including the area surrounding the fields studied (Stenger et al. 2019). In the southeastern United States, bacterial leaf scorch of blueberry is generally associated with strains of $X$. fastidiosa classified as subspecies multiplex, rather than the strains of subspecies fastidiosa, which commonly cause Pierce's disease (Chang et al. 2009). However, some strains of $X$. fastidiosa subspecies fastidiosa are also able to infect blueberry following artificial inoculation (Oliver et al. 2015), and there is increasing evidence to suggest that the $X$. fastidiosa host range can be highly variable among strains within the same subspecies (Nunney et al. 2019). Strain Bakersfield-1, isolated from grapevine in the San Joaquin Valley and characterized as subspecies fastidiosa, contains a plasmid with

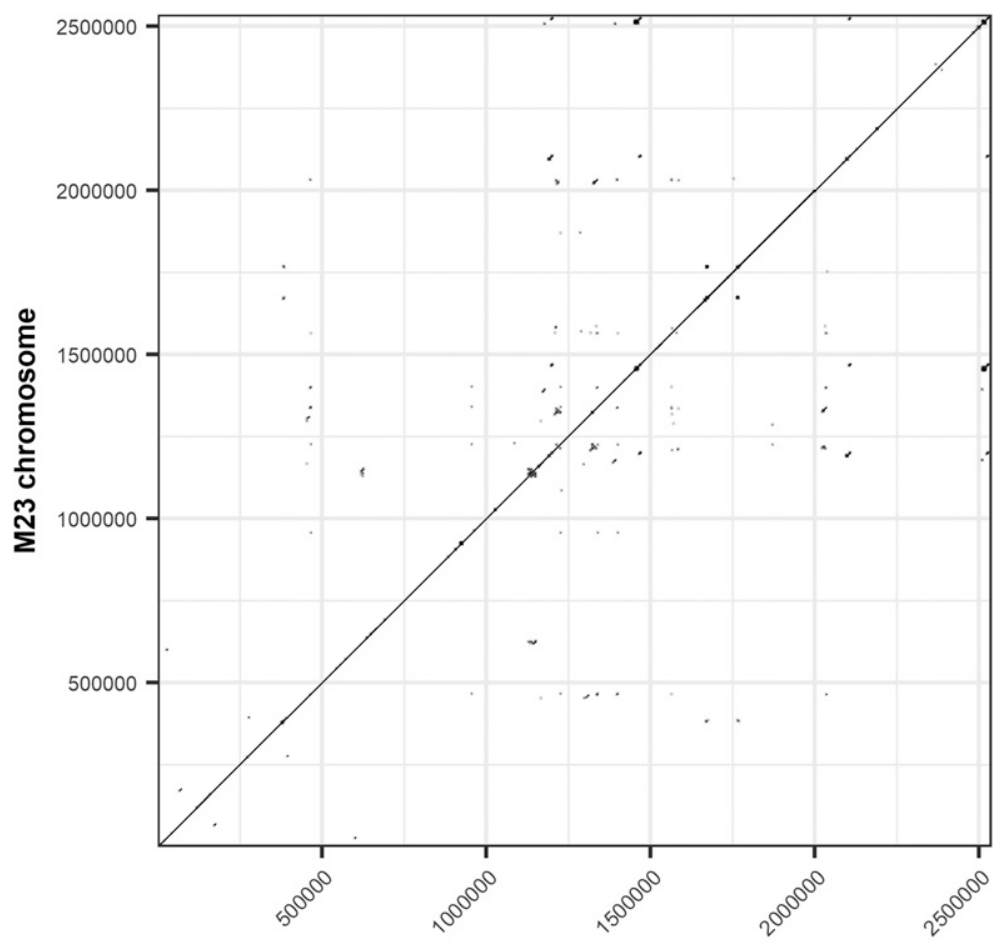

Bakersfield-1 chromosome

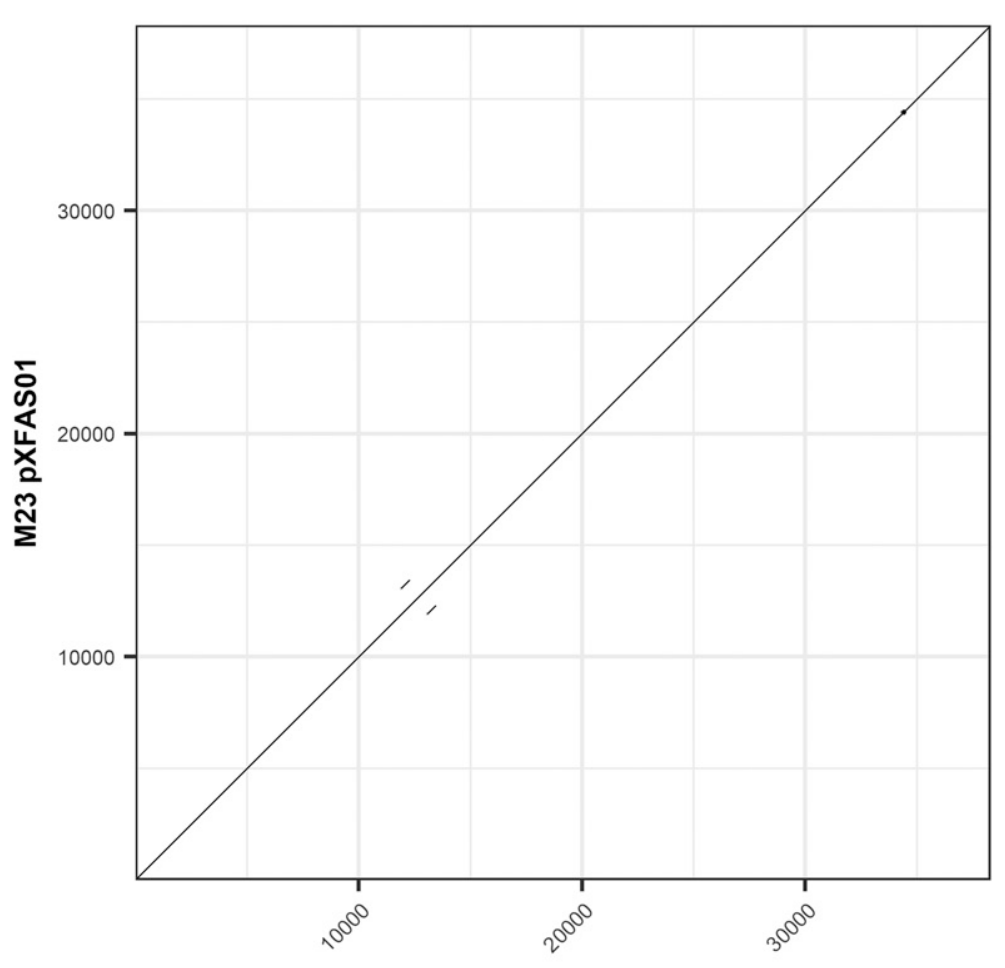

Bakersfield-1 plasmid

Fig. 5. Xylella fastidiosa Bakersfield-1 is genetically similar to strain M23. Synteny plots of $X$. fastidiosa subsp. fastidiosa strains Bakersfield-1 and M23. Top, Nucmer alignment comparing chromosomes of M23 ( $\mathrm{x}$-axis) to Bakersfield-1 (y-axis). Bottom, Nucmer alignment comparing pXFAS01 from M23 (x-axis) to the pXFAS01 homolog present in Bakersfield-1 (y-axis). Nucleotide positions are indicated on both axes in base pairs. 
high sequence similarity to a previously characterized plasmid (pXFAS01) from strain M23, which was originally isolated from almond in central California and also infects grapevine (Burbank and Van Horn 2017; Chen et al. 2005; Chen et al. 2010; Rogers and Stenger 2012) (Fig. 5). The presence of this plasmid and high sequence identity suggest that among the well-described $X$. fastidiosa subsp. fastidiosa strains isolated in California, Bakersfield-1 appears to be the most genetically similar to M23, a strain that was previously not known to infect blueberry.

Strain Bakersfield-1 was able to infect southern high bush blueberry, specifically cv. Emerald, which is known to be resistant to other strains of $X$. fastidiosa (Brannen et al. 2008; Tertuliano et al. 2012). This highlights the importance of understanding varietal and strain differences in evaluating susceptibility to $X$. fastidiosa and risk to new crops. However, the other four cultivars tested in this study did not appear to be susceptible to X. fastidiosa Bakersfield-1, and disease development in 'Emerald' was only moderate compared with bacterial leaf scorch caused by $X$. fastidiosa strains belonging to subspecies multiplex (Chang et al. 2009; Holland et al. 2014). In a field setting, the risk of transmission from blueberry to grape and vice versa would be dependent on cultivar susceptibility (of both crops) to the $X$. fastidiosa strains present in the area and vector population levels. The probability of transmission from grape to blueberry was not directly measured in this study, but given the low efficiency of glassy-winged sharpshooter transmission in other plant species (Almeida and Purcell 2003), it is likely to be low in blueberry as well,
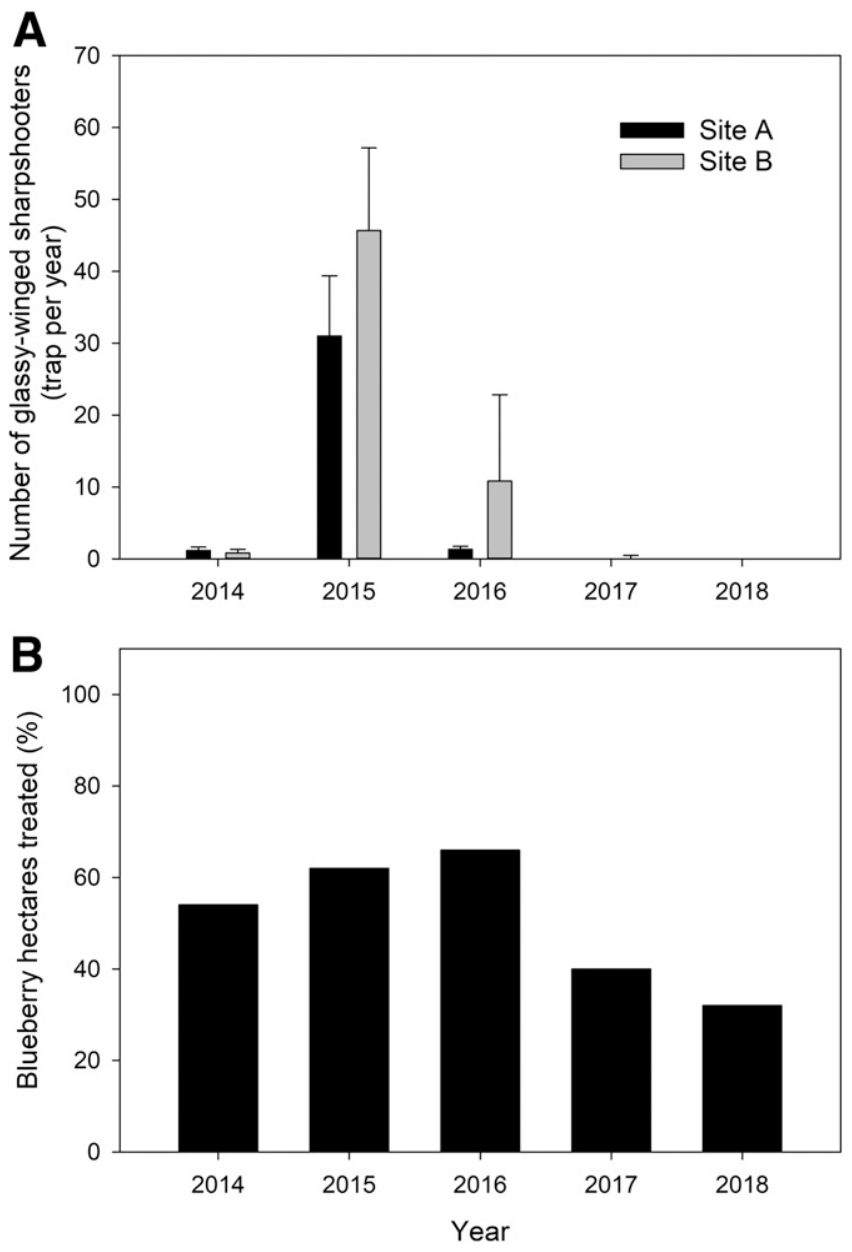

Fig. 6. Glassy-winged sharpshooter abundance and insecticides applied to blueberry fields. A, Mean ( \pm SE) number of glassy-winged sharpshooters caught per year on each trap on the perimeter of blueberry fields $A$ and $B$ that were in an area with $a$ history of increased glassy-winged sharpshooter abundance. B, Percentage of blueberry hectares in Kern County reporting at least one application of insecticide classes that are likely to kill glassy-winged sharpshooters. making the probability of transmission largely dependent on the vector population and plant susceptibility. Therefore, based on the current information, it is likely that the risk of disease in blueberries from $X$. fastidiosa strains causing Pierce's disease in grapevines in the San Joaquin Valley is relatively low unless more susceptible cultivars are planted or X. fastidiosa strains that more aggressively colonize blueberry are introduced.

A related consideration is whether moderately infected blueberries are a potential inoculum source of $X$. fastidiosa relevant to Pierce's disease in grapevine. Although typically considered to be fieldresistant to $X$. fastidiosa, blueberry cv. Emerald was shown to be a preferred feeding host for glassy-winged sharpshooters during choice tests with other blueberry cultivars (Tertuliano et al. 2012). Under laboratory conditions, glassy-winged sharpshooter acquired $X$. fastidiosa from artificially inoculated 'Emerald' blueberry plants during 7 days of feeding (Fig. 4A). Although $38 \%$ of the glassy-winged sharpshooters used in the transmission experiment tested positive for $X$. fastidiosa after the IAP, no transmission to grapevine was observed. Because transmission efficiency of glassy-winged sharpshooters is known to be low compared with other vectors of $X$. fastidiosa, (Almeida and Purcell 2003; Daugherty and Almeida 2009), it is possible that transmission would have occurred at a measurable rate if more vectors were evaluated. The Monte Carlo simulations indicated that the probability of inoculation during the 4-day IAP is likely to be between 0 and 0.13 (Fig. 4B). Because the probability of inoculation may be low, the lack of transmission in these experiments is not conclusive regarding the ability of glassywinged sharpshooters to transmit $X$. fastidiosa between blueberry and grapevine.

Bacterial populations in the plant must reach a certain threshold level before acquisition occurs, which would be influenced by host susceptibility (Hill and Purcell 1997). Once infections have progressed to the point suitable for acquisition, rates of transmission would become dependent on the number of vectors present. During years with high glassy-winged sharpshooter populations in Kern County vineyards, the glassy-winged sharpshooters were caught on traps located on the perimeters of blueberry fields (Fig. 6). The presence of glassy-winged sharpshooters near blueberry fields is dependent on glassy-winged sharpshooter abundance in habitats surrounding blueberry, because insects move out from areas of high population density by random dispersal (Krugner et al. 2012). However, when glassy-winged sharpshooter populations were controlled by area-wide treatments primarily applied to citrus, trap counts were low or zero in blueberry, even though these fields were generally not treated with insecticides targeting glassy-winged sharpshooters (Fig. $6 \mathrm{~B})$. This suggested that blueberry is not a preferred feeding host of glassy-winged sharpshooters in this area where several other crops are present, including grapevine and citrus. Several other blueberry cultivars tested in this study did not become infected from artificial inoculation of an $X$. fastidiosa strain representative of Pierce's disease strains in Kern County. As long as disease is managed in nearby vineyards through insecticide treatments and rogueing, there is probably a limited risk of spread of $X$. fastidiosa to blueberry or of blueberry acting as a reservoir of $X$. fastidiosa for further spread to grape. However, if new strains of $X$. fastidiosa were introduced, or if more susceptible blueberry cultivars were planted, then the risk of bacterial leaf scorch in blueberry in California would need to be re-evaluated.

\section{Acknowledgments}

We thank Sean Uchima, Brandon Ortega, Robert Leija, Nathan Luna, and Sandra Navarro for technical assistance. We thank Adam Porter for sharing code for the random number generator.

\section{Literature Cited}

Almeida, R. P. P., and Purcell, A. H. 2003. Transmission of Xylella fastidiosa to grapevines by Homalodisca coagulata (Hemiptera: Cicadellidae). J. Econ. Entomol. 96:264-271.

Brannen, P., Scherm, H., and Chang, C. 2008. Survey of cultivar differences in bacterial leaf scorch incidence among southern highbush blueberries. Dixie Blueberry News 8:6-7. 
Brettin, T., Davis, J. J., Disz, T., Edwards, R. A., Gerdes, S., Olsen, G. J., Olson, R., Overbeek, R., Parrello, B., Pusch, G. D., Shukla, M., Thomason Iii, J. A., Stevens, R., Vonstein, V., Wattam, A. R., and Xia, F. 2015. RASTtk: A modular and extensible implementation of the RAST algorithm for building custom annotation pipelines and annotating batches of genomes. Sci. Rep. 5:8365.

Burbank, L. P., and Ortega, B. C. 2018. Novel amplification targets for rapid detection and differentiation of Xylella fastidiosa subspecies fastidiosa and multiplex in plant and insect tissues. J. Microbiol. Methods 155:8-18.

Burbank, L. P., and Stenger, D. C. 2016. A temperature-independent cold-shock protein homolog acts as a virulence factor in Xylella fastidiosa. Mol. PlantMicrobe Interact. 29:335-344.

Burbank, L. P., and Van Horn, C. R. 2017. Conjugative plasmid transfer in Xylella fastidiosa is dependent on tra and trb operon functions. J. Bacteriol. 199: e00388-17.

Chang, C.-J., Donaldson, R., Brannen, P., Krewer, G., and Boland, R. 2009. Bacterial leaf scorch, a new blueberry disease caused by Xylella fastidiosa. HortScience 44:413-417.

Chen, J., Groves, R., Civerolo, E. L., Viveros, M., Freeman, M., and Zheng, Y. 2005. Two Xylella fastidiosa genotypes associated with almond leaf scorch disease on the same location in California. Phytopathology 95:708-714.

Chen, J., Xie, G., Han, S., Chertkov, O., Sims, D., and Civerolo, E. L. 2010. Whole genome sequences of two Xylella fastidiosa strains (M12 and M23) causing almond leaf scorch disease in California. J. Bacteriol. 192:4534.

Daugherty, M. P., and Almeida, R. P. P. 2009. Estimating Xylella fastidiosa transmission parameters: decoupling sharpshooter number and feeding period. Entomol. Exp. Appl. 132:84-92.

Ferguson, M., and Clark, C. A. 2017. Xylella Fastidiosa in rabbiteye blueberry: a newly studied host of an old foe. LSU Ag Center. https://www.lsuagcenter.com/ profiles/lbenedict/articles/page1496327441153

Grafton-Cardwell, E. E., Reagan, C. A., and Ouyang, Y. 2003. Insecticide treatments disinfest nursery citrus of glassy-winged sharpshooter. Calif. Agric. 57:128-131.

Harmon, P. F., and Hopkins, D. L. 2009. First report of bacterial leaf scorch caused by Xylella fastidiosa on southern highbush blueberry in Florida. Plant Dis. 93: 1220 .

Haviland, D., and Stone-Smith, B. 2016. Resurgence of the glassy-winged sharpshooter and Pierce's disease in Kern County. San Joaquin Valley Table Grape Seminar, Visalia, CA.

Hernandez-Martinez, R., Costa, H. S., Dumenyo, C. K., and Cooksey, D. A. 2006. Differentiation of strains of Xylella fastidiosa infecting grape, almonds, and oleander using a multiprimer PCR assay. Plant Dis. 90:1382-1388.

Hill, B. L., and Purcell, A. H. 1997. Populations of Xylella fastidiosa in plants required for transmission by an efficient vector. Phytopathology 87:1197-1201.

Hix, R. L. 2002. Control of adult glassy-winged sharpshooter, 2001. Arthropod Management Tests. 27:D1

Holland, R. M., Christiano, R. S. C., Gamliel-Atinsky, E., and Scherm, H. 2014. Distribution of Xylella fastidiosa in blueberry stem and root sections in relation to disease severity in the field. Plant Dis. 98:443-447.

Hopkins, D. L., and Purcell, A. H. 2002. Xylella fastidiosa: cause of Pierce's disease of grapevine and other emergent diseases. Plant Dis. 86:1056-1066.

Jolley, K. A., Chan, M.-S., and Maiden, M. C. J. 2004. mlstdbNet - distributed multi-locus sequence typing (MLST) databases. BMC Bioinformatics 5:86.

Koren, S., Walenz, B. P., Berlin, K., Miller, J. R., Bergman, N. H., and Phillippy, A. M. 2017. Canu: scalable and accurate long-read assembly via adaptive k-mer weighting and repeat separation. Genome Res. 27:722-736.

Krugner, R., Hagler, J. R., Groves, R. L., Sisterson, M. S., Morse, J. G., and Johnson, M. W. 2012. Plant water stress effects on the net dispersal rate of the insect vector Homalodisca vitripennis (Hemiptera: Cicadellidae) and movement of its egg parasitoid, Gonatocerus ashmeadi (Hymenoptera: Mymaridae). Environ. Entomol. 41:1279-1289.

Krugner, R., Sisterson, M. S., Backus, E. A., Burbank, L. P., and Redak, R. A. 2019. Sharpshooters: a review of what moves Xylella fastidiosa. Aust. Entomol. 58:248-267.
Kück, P., and Longo, G. C. 2014. FASconCAT-G: extensive functions for multiple sequence alignment preparations concerning phylogenetic studies. Front. Zool. 11:81.

Kumar, S., Stecher, G., Li, M., Knyaz, C., and Tamura, K. 2018. MEGA X: molecular evolutionary genetics analysis across computing platforms. Mol Biol. Evol. 35:1547-1549.

Kurtz, S., Phillippy, A., Delcher, A. L., Smoot, M., Shumway, M., Antonescu, C., and Salzberg, S. L. 2004. Versatile and open software for comparing large genomes. Genome Biol. 5:R12.

Leonberger, K., and Gauthier, N. W. 2015. First report of bacterial leaf scorch of blueberry in Kentucky. https://kentuckypestnews.wordpress.com/2015/11/17/ first-report-of-bacterial-leaf-scorch-of-blueberry-in-kentucky/

Loman, N. J., Quick, J., and Simpson, J. T. 2015. A complete bacterial genome assembled de novo using only Nanopore sequencing data. Nat. Methods 12: 733-735.

Löytynoja, A., and Goldman, N. 2010. webPRANK: a phylogeny-aware multiple sequence aligner with interactive alignment browser. BMC Bioinformatics 11 579

Manly, B. F. J. 2001. Randomization, bootstrap, and Monte Carlo methods in biology. Chapman and Hall, Boca Raton, FL.

National Agricultural Statistics Service. 2019. United States Department of Agriculture, National Agricultural Statistics Service. https://www.nass.usda.gov/ Quick_Stats/

Nunney, L., Azad, H., and Stouthamer, R. 2019. An experimental test of the hostplant range of nonrecombinant strains of North American Xylella fastidiosa subsp. multiplex. Phytopathology 109:294-300.

Nunney, L., Schuenzel, E. L., Scally, M., Bromley, R. E., and Stouthamer, R. 2014. Large-scale intersubspecific recombination in the plant-pathogenic bacterium Xylella fastidiosa is associated with the host shift to mulberry. Appl. Environ. Microbiol. 80:3025-3033.

Oliver, J. E., Cobine, P. A., and De La Fuente, L. 2015. Xylella fastidiosa isolates from both subsp. multiplex and fastidiosa cause disease on southern highbush blueberry (Vaccinium sp.) under greenhouse conditions. Phytopathology 105: 855-862.

Perring, T. M., Farrar, C. A., and Blua, M. 2001. Proximity to citrus influences Pierce's disease in Temecula Valley vineyards. Calif. Agric. 55:13-18.

Prabhaker, N., Castle, S., Byrne, F., Henneberry, T. J., and Toscano, N. C. 2006 Establishment of baseline susceptibility data to various insecticides for Homalodisca coagulata (Homoptera: Cicadellidae) by comparative bioassay techniques. J. Econ. Entomol. 99:141-154.

Rapicavoli, J. N., Kinsinger, N., Perring, T. M., Backus, E. A., Shugart, H. J. Walker, S., and Roper, M. C. 2015. O antigen modulates insect vector acquisition of the bacterial plant pathogen Xylella fastidiosa. Appl. Environ. Microbiol. 81:8145-8154.

Rogers, E. E., and Stenger, D. C. 2012. A conjugative $38 \mathrm{~kb}$ plasmid is present in multiple subspecies of Xylella fastidiosa. PLoS One 7:e52131.

Scally, M., Schuenzel, E. L., Stouthamer, R., and Nunney, L. 2005. Multilocus sequence type system for the plant pathogen Xylella fastidiosa and relative contributions of recombination and point mutation to clonal diversity. Appl. Environ. Microbiol. 71:8491-8499.

Sisterson, M. S. 2014. Evaluation of a method to quantify glassy-winged sharpshooter (Hemiptera: Cicadellidae) egg maturation during a feeding assay. J. Econ. Entomol. 107:206-214.

Stenger, D. C., Burbank, L. P., Krugner, R., and Sisterson, M. S. 2019. Individual field-collected glassy-winged sharpshooter vectors harbor sequences from two Xylella fastidiosa subspecies. Eur. J. Plant Pathol. 155:329-338.

Tertuliano, M., Srinivasan, R., and Scherm, H. 2012. Settling behavior of the glassy-winged sharpshooter, Homalodisca vitripennis, vector of Xylella fastidiosa, on southern highbush blueberry cultivars. Entomol. Exp. Appl. 143:67-73.

Van Horn, C., Chang, C.-J., and Chen, J. 2017. De novo whole-genome sequence of Xylella fastidiosa subsp. multiplex strain BB01 isolated from a blueberry in Georgia, USA. Genome Announc. 5:e01598-16. 